UDC 621.35

\author{
O.I. Kuntyi, G.I. Zozulya, M.V. Shepida, S.I. Nichkalo
}

\title{
DEPOSITION OF NANOSTRUCTURED METALS ON THE SURFACE OF SILICON BY GALVANIC REPLACEMENT: A MINI-REVIEW
}

\author{
Lviv Polytechnic National University, Lviv, Ukraine
}

\begin{abstract}
The paper overviews the publications of the last decade devoted to the formation of metallic nanostructures on the surface of the silicon substrate by the galvanic replacement method. Among modern methods of surface modification by nanostructures, galvanic replacement can be considered as one of the most effective in the aspect of obtaining new materials and applying metal films. The deposits of silicon nanostructures of silver, gold, platinum metals and copper are the most studied. The features of microelectrode reactions with the participation of the semiconductor and the components of the solution are discussed. The methods of metal nanoparticles and nanofilms deposition on the silicon wafer surface are reviewed. The data on the influence of the main parameters of the galvanic replacement process (composition of the solution, duration of precipitation and temperature) on the deposits' morphology and the geometry of the deposited particles are presented. The main directions in the application of metal-silicon hybrid structures obtained by galvanic replacement, namely metal-catalytic chemical etching, creation of electrical contacts on the surface of silicon and high-performance catalysts and sensors, are described. It has been shown that the galvanic replacement method provides controlled synthesis of metal nanoparticles of defined morphology, shape, size and distribution on the surface of silicon substrate and their special functional properties.
\end{abstract}

Keywords: galvanic replacement, silicon, nanoparticles, silver, gold, platinum, palladium, copper.

DOI: $10.32434 / 0321-4095-2019-124-3-74-82$

\section{Introduction}

A surface of silicon modified by nanoparticles of metals has a number of special functional properties, which determine a wide range of its application. In particular, the application of nanoparticles of noble metals contributes to the local metal-catalytic chemical etching (MCCE) of the silicon substrate to produce a homogeneous porous layer or nanowalls [1-6]. The MCCE method can be applied to create an antireflective surface for highly efficient solar cells [1,2], energy storage devices [3], chemical and biological sensors [4,5] as well as for the production of superhydrophobic materials [6].

Metallization of a silicon surface with gold in the form of nanofilms or discrete particles is widely used for the formation of electrical contacts [7-10]. In a metal-semiconductor hybrid structure (a surface system of $\mathrm{M} / \mathrm{Si}$ ), the silicon substrate facilitates the formation of electron-deficient metal nanoparticles that increases their catalytic activity $[11,12]$. In addition, such structures lead to the formation of a Schottky barrier in which the current flows in one direction: from metal to semiconductor what is used in diodes and transistors [13]. It is also known that silver nanoparticles on porous silicon surfaces exhibit a high antibacterial activity $[14,15]$.

Among the methods used to modify the silicon surface by metal nanoparticles and determine their geometry and distribution on the surface, one can distinguish such as physical (thermal evaporation [16], sputtering of the electron beam [17], laser treatment [18]), chemical [19] and physico-chemical (electrodeposition [20-23], galvanic replacement [24-44]) techniques. However, most of the methods are energy consuming and require the use of expensive equipment. Therefore, one of the effective methods of deposition of nanostructural metal nanoparticles and nanofilms on a semiconductor silicon surface is a galvanic replacement, which is simple to execute, and does not require additional 
equipment and reagent-reducing agents.

Over the past two decades, there was observed a growth of the number of publications devoted to the use of galvanic replacement process to fabricate a metal-silicon hybrid structure. However, practically all these papers are mainly directed to the case studies of the methods of deposition of individual metals on a silicon surface and the characterization of the resulting deposits. The last review article aiming to the deposition of nanostructured metals on the surface of semiconductors by the galvanic replacement method was published in 2007 [28]. In view of the increased interest in this trend of research in the last decade, the aim of this mini-review is to analyze the current state of the formation of metallic nanostructures on the silicon wafer surface, and the dependences of the morphology of deposited metals on the main factors of the process. surface

Mechanism of galvanic replacement on a silicon

Galvanic replacement is considered as a specific electrochemical process which passes without spatial separation of anode and cathode regions. The latter arise simultaneously as a result of contact with a more electronegative element with a solution containing ions of less electronegative metal. On the surface of silicon, the galvanic replacement occurs in general by reaction (1) via electrochemical mechanism and involves an electrically generating semi-reaction of oxidation of a silicon substrate at microanodes (2) and a semi-reaction of metal reduction at microcathodes (3).

$\mathrm{nSi}+4 \mathrm{M}^{+\mathrm{n}} \rightarrow \mathrm{nSi}^{+4}+4 \mathrm{M}$.

Microanode: $\mathrm{nSi} \rightarrow \mathrm{nSi}^{4+}+4 n e$.

Microcathode: $4 \mathrm{M}^{+\mathrm{n}}+4 \mathrm{ne} \rightarrow 4 \mathrm{M}$.

According to the thermodynamic principles, the spontaneous flow of galvanic replacement on the silicon surface is possible if the following inequality is valid:

$-\frac{\Delta \mathrm{G}}{\mathrm{nE}}=\left(\mathrm{E}_{\mathrm{M}^{\mathrm{n}+} / \mathrm{M}}-\mathrm{E}_{\mathrm{Si}^{4+} / \mathrm{Si}}\right)>0$,

where $\Delta \mathrm{E}$ is the electromotive force of the process; $\mathrm{F}$ is the Faraday constant; $\mathrm{n}$ is the number of electrons involved in the process; and $\mathrm{E}_{\mathrm{M}^{\mathrm{n}+} / \mathrm{M}}$, $\mathrm{E}_{\mathrm{Si}^{4+} / \mathrm{Si}}$ are the equilibrium potentials.

Thus, galvanic replacement occurs if the value of the equilibrium potential of the reducing agent (silicon) $\mathrm{E}_{\mathrm{Si}^{4+} / \mathrm{Si}}$ is less than that of the oxidizer (the recoverable metal) $\mathrm{E}_{\mathrm{M}^{\mathrm{n}+} / \mathrm{M}}$.

The deposit morphology and the particles size on the substrate surface depend, first of all, on the difference of the electrode potentials, $\Delta \mathrm{E}=\mathrm{E}_{\mathrm{M}^{\mathrm{n} /} / \mathrm{M}}-\mathrm{E}_{\mathrm{Si}^{4+} / \mathrm{Si}}$. The latter is a multifactor quantity which depends primarily on the standard potential of a reducible metal, its ion concentration, solution composition and temperature. In addition, $\Delta \mathrm{E}$ can change in time as the area of the anode sections decreases due to the growth of cathodic ones. The higher the value of $\Delta \mathrm{E}$, the greater are the rate of the process (1) and the current density values on the microcathodes. This contributes to the predominant nucleation and formation of submicron and nano-sized deposits.

High affinity of $\mathrm{Si}^{4+}$ ions to oxygen causes their hydrolysis in neutral and acidic mediums. This forms an insoluble $\mathrm{SiO}_{2} \cdot \mathrm{xH}_{2} \mathrm{O}$ that passivates the silicon surface. Therefore, ions $\mathrm{F}^{-}$, which form stable and well-soluble complexes $\left[\mathrm{SiF}_{6}\right]^{2-}$, prevent hydrolysis in aqueous solutions at $\mathrm{pH}<12$. The reaction of complex formation (Eq. (5)) occurs in the fluoridecontaining solution on the microanode after the ionization of silicon [26-30], while the formation of a soluble silicate anion (Eq. (6)) proceeds in an alkaline solution $(\mathrm{pH}>12)$ [31]. The process of metal deposit formation on the surface of silicon is schematically depicted in Figure where the course of these microanodic and microcathodes reactions is taken into account.

$$
\begin{aligned}
& \mathrm{Si}+6 \mathrm{~F}^{-} \rightarrow\left[\mathrm{SiF}_{6}\right]^{2-}+4 \mathrm{e}\left(\mathrm{E}^{0}=-1.2 \mathrm{~V}\right) \\
& \mathrm{Si}+6 \mathrm{OH}^{-} \rightarrow \mathrm{SiO}_{3}{ }^{2-}+3 \mathrm{H}_{2} \mathrm{O}+4 \mathrm{e}\left(\mathrm{E}^{0}=-1.73 \mathrm{~V}\right)
\end{aligned}
$$

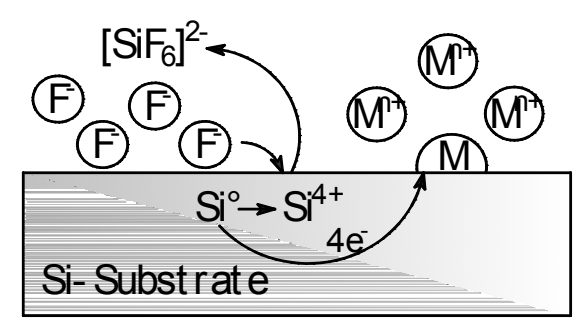

Schematic representation of the galvanic replacement mechanism of metals on silicon substrate

Comparing the values of the standard electrode potentials of silicon in fluoride (5) and highly alkaline (6) solutions, one can conclude that the latter provides higher values of electromotive force of galvanic replacement. However, the insolubility of the hydroxides of reducing metals and the instability of most complexes at $\mathrm{pH}>12$ limit their practical 
implementation. In addition, there are side reactions (7) and (8) in an highly alkaline environment which causes destruction of the silicon surface and its shielding with microbubbles of hydrogen. This complicates an even distribution of metal particles on the substrate surface, and limits the application of such a method in nanotechnology. Therefore, the deposition of nanostructured metals on the surface of silicon by galvanic replacement is carried out predominantly in fluoride-containing solutions (Table).

$$
\begin{aligned}
& \mathrm{Si}+2 \mathrm{OH}^{-}+\mathrm{H}_{2} \mathrm{O} \rightarrow \mathrm{SiO}_{3}{ }^{2-}+2 \mathrm{H}_{2} \\
& \mathrm{Si}+4 \mathrm{OH}^{-} \rightarrow \mathrm{SiO}_{3}{ }^{2-}+\mathrm{H}_{2} \mathrm{O}+\mathrm{H}_{2}+2 \mathrm{e}
\end{aligned}
$$

\section{Main factors influencing the morphology of deposited metal}

Metal reduction during galvanic replacement is a spontaneous and multifactorial process that complicates the controlled formation of the metal deposit, in particular the geometry of its structural particles, their density on the surface and the adhesion to the substrate. Therefore, the studies of the formation of metal nanoparticles on a silicon surface are mainly focused on the determination of the dependences of the morphology of precipitated metal on such factors of the galvanic replacement as the composition of the solution, duration of the process and temperature (Table).

The composition of the solution involves the

\begin{tabular}{|c|c|c|c|c|c|c|}
\hline Metal & $\begin{array}{l}\text { Type of silicon } \\
\text { substrate }\end{array}$ & The composition of the solution & $\begin{array}{l}\text { Temperature, } \\
{ }^{0} \mathrm{C} \\
\end{array}$ & $\begin{array}{c}\text { Duration of the } \\
\text { process }\end{array}$ & $\begin{array}{c}\text { Particle size, } \\
\mathrm{nm}\end{array}$ & Ref. \\
\hline \multirow{10}{*}{$\mathrm{Ag}$} & n-Si (111) & $0.02 \mathrm{mM} \mathrm{AgNO}_{3}$ and $0.15 \mathrm{M} \mathrm{HF}$ & 5 & $1 \ldots 15 \mathrm{~s}$ & 50 & {$[24]$} \\
\hline & $\begin{array}{c}\mathrm{n}-\mathrm{Si}(100),(110), \\
(111)\end{array}$ & 4.5 M HF and $0.02 \mathrm{MAgNO}_{3}$ & 40 & $1 \mathrm{~min}$ & 100 & {$[26]$} \\
\hline & $\mathrm{Si}(111)$ & $1 \mathrm{mM} \mathrm{AgNO}_{3}$ and $9 \mathrm{M} \mathrm{HF}$ & - & $5,30,60 \mathrm{~s}$ & $400-1000$ & {$[27]$} \\
\hline & n-Si; p-Si & $6.0 \mathrm{mM}\left[\mathrm{Ag}\left(\mathrm{NH}_{3}\right)_{2}\right]^{+}$ & $85 ; 23$ & $10 \mathrm{~min} ; 72 \mathrm{~h}$ & $500 ; 10-100$ & {$[31]$} \\
\hline & Si wafer & $0.1-0.5 \mathrm{mM} \mathrm{AgNO}_{3}$ and PVP $(6 \mathrm{mM})$ & 23 & $1,3,5 \mathrm{~min}$ & $20-300$ & {$[32]$} \\
\hline & n-Si (100) & $1.0 \mathrm{mM} \mathrm{AgNO}_{3}$ & 5 & $5 \mathrm{~s}$ & $9-60$ & {$[33]$} \\
\hline & Si (100) & $27.82 \mathrm{M} \mathrm{HF}$ and $0.05 \mathrm{M} \mathrm{AgNO}_{3}$ and $\mathrm{H}_{2} \mathrm{O}$ & 23 & $30 \mathrm{~s}$ & $70-170$ & {$[34]$} \\
\hline & n-Si (100) & $0.15 \mathrm{M} \mathrm{HF}$ and $1 \mathrm{mM} \mathrm{AgNO}$ & 5 & $5 \mathrm{~s}$ & 9 & [35] \\
\hline & $\mathrm{p}-\mathrm{Si}(100)$ & $0.15 \mathrm{M} \mathrm{HF}$ and $1 \mathrm{mM} \mathrm{\textrm {AgNO } _ { 3 }}$ & 5 & $10 \mathrm{~s}$ & $10-30$ & [36] \\
\hline & n-Si (100) & $0.15 \mathrm{M} \mathrm{HF}$ and $1 \mathrm{mM} \mathrm{AgNO}_{3}$ & 40 & $120 \mathrm{~s}$ & $20-300$ & {$[37]$} \\
\hline \multirow{7}{*}{$\mathrm{Au}$} & Si (100), Si (111) & $0.1 \mathrm{mM} \mathrm{KAuCl}_{4}$ and $1 \% \mathrm{HF}$ & 25 & $\begin{array}{c}30 \mathrm{~s} \\
2.5 \ldots 7.5 \mathrm{~min}\end{array}$ & $20-100$ & {$[7]$} \\
\hline & $\mathrm{Si}(100)$ & $2,0.2,0.02 \mathrm{M} \mathrm{KAuCl}_{4}$ & - & $5 \ldots 900 \mathrm{~s}$ & 1 & {$[10]$} \\
\hline & $\mathrm{Si}(100)$ & $0.5 \mathrm{mM} \mathrm{HAuCl}_{4}$ & 5 & $120 \mathrm{~s}$ & $6-25$ & {$[30]$} \\
\hline & Si (100) & $0.15 \mathrm{M} \mathrm{HF}$ and $1 \mathrm{mM} \mathrm{AuCl} 3$ & 23 & $10 \mathrm{~min}$ & 100 (film) & {$[34]$} \\
\hline & n-Si (100) & $0.15 \mathrm{M} \mathrm{HF}$ and $0.5 \mathrm{mM} \mathrm{HAuCl}_{4}$ & 5 & $10 \mathrm{~s}$ & 5 & {$[35]$} \\
\hline & n-Si (100) & $0.15 \mathrm{M} \mathrm{HF}^{2}$ and $1 \mathrm{mM} \mathrm{HAuCl}$ & 40 & $120 \mathrm{~s}$ & $5-70$ & {$[37]$} \\
\hline & n, p-Si (111); (100) & $0.1 \ldots 1 \mathrm{mM} \mathrm{KAuCl}_{4}$ and $5 \mathrm{M} \mathrm{HF}$ & 23 & $5 \mathrm{~s} ; 60 \mathrm{~s}$ & $10-30$ & {$[38]$} \\
\hline $\mathrm{Pt}-\mathrm{Au}$ & p-Si (100) & $\begin{array}{c}2 \mathrm{mM} \mathrm{HAuCl}_{4} \\
1 \mathrm{mM} \mathrm{K}_{2} \mathrm{PtCl}_{6} \text { and } 0.5 \mathrm{M} \mathrm{HF}\end{array}$ & - & $3 \mathrm{~min}$ & $30-50$ & {$[39]$} \\
\hline \multirow{5}{*}{$\mathrm{Cu}$} & n-Si (111) & $0.01 \mathrm{M} \mathrm{CuSO}_{4}$ and $1.2 \mathrm{M} \mathrm{HF}$ & 40 & $15 \mathrm{~min}$ & 100 & {$[40]$} \\
\hline & n-Si (111) & $10 \mathrm{mM} \mathrm{CuSO}_{4}$ & 25 & $60 \mathrm{~min}$ & $60-120$ & {$[41]$} \\
\hline & n-Si (111) & $10 \mathrm{mM} \mathrm{CuSO}_{4}$ & 25 & $10 \mathrm{~s}, 1 \mathrm{~min}, 1 \mathrm{~h}$ & $10-200$ & [42] \\
\hline & Si (100) & $3.0 \mathrm{MHF}$ and $1 \ldots 20 \mathrm{mMCuSO}_{4}$ & 25 & $10 ; 1800 \mathrm{~s}$ & $150-200$ & {$[25]$} \\
\hline & n-Si (100) & $0.15 \mathrm{M} \mathrm{HF}$ and $1 \mathrm{mM} \mathrm{CuCl}_{2}$ & 40 & $120 \mathrm{~s}$ & $20-300$ & {$[37]$} \\
\hline \multirow{4}{*}{$\mathrm{Pd}$} & $\mathrm{Si}(100)$ & $0.15 \mathrm{M}\left(\mathrm{PdCl}_{2}\right.$ and $\left.\mathrm{KF}, \mathrm{KCl}\right)$ & - & $5 \ldots 90 \mathrm{~s}$ & $50-100$ & {$[43]$} \\
\hline & Si (100) & $0.15 \mathrm{M} \mathrm{HF}$ and $1 \mathrm{mM} \mathrm{PdCl} 2$ & 23 & $10 \min$ & 140 & {$[34]$} \\
\hline & p-Si (100) & $0.15 \mathrm{M} \mathrm{HF}$ and $1 \mathrm{mM} \mathrm{PdCl}_{2}$ & 40 & $30 \mathrm{~s}$ & $50-150$ & {$[36]$} \\
\hline & $\mathrm{n}-\mathrm{Si}(100)$ & $0.15 \mathrm{M} \mathrm{HF}$ and $1 \mathrm{mM} \mathrm{PdCl}_{2}$ & 40 & $120 \mathrm{~s}$ & $20-300$ & {$[37]$} \\
\hline $\mathrm{Ni}$ & n-Si (100) & $\begin{array}{c}0.1 \mathrm{M} \mathrm{NiSO}_{4} \text { and } 0.2 \ldots 0.5 \mathrm{M}\left(\mathrm{NH}_{4}\right)_{2} \mathrm{SO}_{4} \\
{\left[\mathrm{Ni}\left(\mathrm{NH}_{3}\right)_{\mathrm{n}}\left(\mathrm{H}_{2} \mathrm{O}\right)_{6-\mathrm{n}}\right]^{2+}(\mathrm{n}=3-4)}\end{array}$ & $60-80$ & - & $<200$ & {$[44]$} \\
\hline \multirow{2}{*}{$\mathrm{Pt}$} & n-Si (100) & $0.15 \mathrm{M} \mathrm{HF}$ and $1 \mathrm{mM} \mathrm{H}_{2} \mathrm{PtCl}_{6}$ & 40 & $90 \mathrm{~s}$ & 50 & [35] \\
\hline & $\mathrm{n}-\mathrm{Si}(100)$ & $0.15 \mathrm{M} \mathrm{HF}$ and $1 \mathrm{mM} \mathrm{H}_{2} \mathrm{PtCl}_{6}$ & 40 & $120 \mathrm{~s}$ & $5-70$ & {$[37]$} \\
\hline \multirow{2}{*}{$\mathrm{Rh}$} & $\mathrm{n}-\mathrm{Si}(100)$ & $0.15 \mathrm{M} \mathrm{HF}$ and $1 \mathrm{mM} \mathrm{RhCl} 3$ & 40 & $120 \mathrm{~s}$ & 60 & {$[35]$} \\
\hline & n-Si (100) & $0.15 \mathrm{M} \mathrm{HF}$ and $1 \mathrm{mM} \mathrm{RhCl} 3$ & 40 & $120 \mathrm{~s}$ & $20-300$ & {$[37]$} \\
\hline
\end{tabular}

Conditions of the formation of metal nanoparticles on the silicon surface by galvanic replacement 
nature of the metal ion (hydrated or complex one), its concentration, the presence of a surfactant and the nature of the medium (aqueous or non-aqueous).

Solutions of hydrated ions are used for deposition of copper $[25,37,40-42]$, silver $[24,26,27,31-37]$, palladium $[34,36,37,43]$ and rhodium [35,37], where the formation of nanoparticles is provided by the concentration polarization due to the low content of metal salt $(0.1-10 \mathrm{mM})$. The deposition of nanostructured gold $[13,37]$, platinum [35,37] and nickel [44] is carried out from complex solutions. The literature sources do not describe the comparison of the effects of hydrated and complex ions on the formation of deposit morphology and the size of structural particles obtained by galvanic replacement. This is due to extremely wide range of the concentration factor by which it is possible to control the geometry of nanoparticles and their size distribution. As a result, it is difficult to comprehensively generalize the effect of this factor. For example, with a decrease of the concentration of $\mathrm{AgNO}_{3}$ from $0.1 \mathrm{mM}$ to $0.001 \mathrm{mM}$, the size of silver nanoparticles is reduced from 10$40 \mathrm{~nm}$ to $3-5 \mathrm{~nm}$, respectively [24].

The surfactants in solutions are commonly used for the «smoothing» effect, influencing the shape of the particles. For instance, nanostructured silver dendritic deposits are formed on the silicon surface in a solution of $\mathrm{AgNO}_{3}$, whereas the presence of polyvinylpyrrolidone (PVP) in such solutions yields spherical nanoparticles [32].

As mentioned above, aqueous solutions cause a number of side-processes during galvanic replacement, which complicates the controlled formation of nanostructured metal deposits on a substrate. Therefore, attention was drawn in the last decade to use the environment of organic solvents, in particular aprotic ones [45-47], where practically only the main electrochemical reactions occur (ionization of the substrate material and the reduction of metal ions). In addition, in such media, the absence of hydrolysis simplifies the composition of the solution, and high-donor organic molecules often perform the functions of surfactant. For example, it was shown [46] that dimethyl sulphoxide (DMSO) medium yields smaller and only spherical gold nanoparticles on the surface of silicon as compared with aqueous solutions. The authors [47] proposed the deposition of nanosized particles of silver, palladium and gold on the surface of silicon in a medium of DMSO and DMF. It is shown that regardless of the nature of the ion of the reducing metal, the silicon surface is filled with spherical particles [47] which is due to adsorption of high- donor molecules of DMF or DMSO (L) at the metal nuclei with the formation of surface complexes under the donor-acceptor mechanism M $\square \leftarrow: L$.

The duration of the galvanic replacement is a factor affecting the size of the deposit particles and their density on the surface, since both the nucleation and the growth of the formed clusters and nanoparticles simultaneously occur. At the same time, there is an expansion of the range of particle size distribution. For instance, with an increase in the duration of silver precipitation from 1 to $15 \mathrm{~s}$ in the solution of $0.001 \mathrm{mM} \mathrm{AgNO}_{3}$, the average size of nanoparticles increases from 5 to $8 \mathrm{~nm}$, and the range changes from $3-8$ to $3-13 \mathrm{~nm}$ [24].

An increase in temperature causes depolarization at microelectrodes which leads to an increase in the rates of an electrogeneric reaction (2) and the recovery of metal ions (3). Correspondingly, the value of currents on microcatodes increases which can significantly affect the morphology of the deposit and the geometry of structural particles [47]. Therefore, the temperature should be selected according to the nature of the ions of the reduced metal (see Table).

\section{Applications of metal-silicon hybrid structure}

Metal-catalytic chemical etching is based on the formation of a galvanic pair of $\mathrm{M} / \mathrm{Si}$ between the deposited nanoparticles of electrically acceptable metals $\mathrm{M}(\mathrm{Ag}, \mathrm{Au}, \mathrm{Pt}$, and $\mathrm{Pd})$ and the silicon surface. In the etching solution $\left(\mathrm{H}_{2} \mathrm{O}_{2}, \mathrm{HF}\right)$, local etching of the substrate occurs $[48,49]$ due to reactions $(9)$ and (10).

$$
\begin{aligned}
& \mathrm{Si}+2 \mathrm{H}_{2} \mathrm{O}_{2} \rightarrow \mathrm{SiO}_{2}+2 \mathrm{H}_{2} \mathrm{O} \\
& \mathrm{SiO}_{2}+6 \mathrm{HF} \rightarrow \mathrm{H}_{2}\left[\mathrm{SiF}_{6}\right]+2 \mathrm{H}_{2} \mathrm{O}
\end{aligned}
$$

The morphology of the etched surfaces varies depending on the type of noble metal, the geometry of the deposited particles and their distribution on the surface. Thus, when using the discrete silver and gold nanoparticles on the substrate in the MCCE method, straight pores are predominantly formed [48,49], while platinum is screw-like [49].

In the presence of discrete nano-sized particles of noble metal, it is possible to obtain legible nanopores, and their high density on the silicon wafer surface produces an array of nanowires with relatively uniform dimensions and distances between them [51].

The nature of the metal, in particular the value of its standard electrode potential, affects the depth of the formed nanopores or the nanowire length. Thus, compared to deposited silver nanoparticles, particles of more electro-positive gold allow 
fabricating silicon nanowires with an ultra-high aspect ratio $(>200)[52]$.

One of the directions of practical use of metalsilicon hybrid structures obtained by galvanic replacement is their use as high-performance catalysts and sensors. Ref. [11] reported high catalytic characteristics of nanostructured $\mathrm{Pd} / \mathrm{Si}$ system toward selective electrochemical hydrogenation of parachlornitrobenzene. The electrochemical sensor based on the $\mathrm{Ag} / \mathrm{Si}$ system [12] provides high selectivity in detecting of hydrogen peroxide. Silicon electrodes modified by nano-particles of noble metals are effective for obtaining hydrogen by photoelectrochemical method [39,53].

Because of galvanic replacement, the deposition of nanostructured metal films on the silicon surface can be performed to create electrical contacts. The most effective in microelectronics are nanofilms of gold which are characterized by high adhesion to the substrate [7-10]. Moreover, both the surface of a simple configuration and the surface of a complex profile configuration may be metallized by this method. Ref. [7] showed the possibility of deposition of gold nanofilm on silicon nanowires.

\section{Acknowledgments}

This research is performed under the project «Controlled electrochemical synthesis of metal nanoparticles and nanostructured materials» (State Registration No. 0118U000268).

\section{REFERENCES}

1. Peng K.-Q., Lee S.-T. Silicon nanowires for photovoltaic solar energy conversion // Adv. Mater. - 2011. - Vol.23. P.198-215.

2. Silicon nanostructures produced by modified MacEtch method for antireflective Si surface / Nichkalo S., Druzhinin A., Evtukh A., Bratus' O., Steblova O. // Nanoscale Res. Lett. 2017. - Vol.12. - Article No. 106.

3. Silicon nanowires for rechargeable lithium-ion battery anodes / Peng K., Jie J., Zhang W., Lee S.-T. // Appl. Phys. Lett. - 2008. - Vol.93. - Article No. 033105.

4. Large-area silver-coated silicon nanowire arrays for molecular sensing using surface-enhanced Raman spectroscopy / Zhang B., Wang H., Lu L., Ai K., Zhang G., Cheng X. // Adv. Funct. Mater. - 2008. - Vol.18. - P.2348-2355.

5. A surface-enhanced Raman spectroscopy substrate for highly sensitive label-free immunoassay / Zhang M.-L., Yi C.-Q., Fan X., Peng K.-Q., Wong N.-B., Yang M.-S., Zhang R.-Q., Lee S.-T. // Appl. Phys. Lett. - 2008. - Vol.92. - Article No. 043116 .

6. Hierarchical silicon etched structures for controlled hydrophobicity/superhydrophobicity / Xiu Y., Zhu L., Hess D.W.,
Wong C.P. // Nano Lett. - 2007. - Vol.7. - P.3388-3393.

7. Heteroepitaxial growth of gold nanostructures on silicon by galvanic displacement / Sayed S.Y., Wang F., Malac M., Meldrum A., Egerton R.F., Buriak J.M. // ACS Nano. - 2009. - Vol.3. - P.2809-2817.

8. Effect of epitaxial growth of gold nanoparticles on $\mathrm{Si}$ substrates on adhesion of electrolessly deposited metal films / Yamada N., Atsushiba H., Sakamoto S., Fukumuro N., Yae S. // ECS Trans. - 2015. - Vol.69. - P.59-63.

9. Raygani A., Magagnin L. Gold metallization of silicon by galvanic displacement // ECS Trans. - 2012. - Vol.41. P.3-8.

10. Gutes A., Carraro C., Maboudian R. Ultrasmooth gold thin films by self-limiting galvanic displacement on silicon // ACS Appl. Mater. Interfaces. - 2011. - Vol.3. - P.1581-1584.

11. $P d$-on-Si catalysts prepared via galvanic displacement for the selective hydrogenation of para-chloronitrobenzene / Wei Q., Shi Y.-S., Sun K.-Q., Xu B.-Q. // Chem. Commun. 2016. - Vol.52. - P.3026-3029.

12. Ensafi A.A., Rezaloo F., Rezaei B. Electrochemical sensor based on porous silicon/silver nanocomposite for the determination of hydrogen peroxide // Sens. Actuators B. - 2016. - Vol.231. P.239-244.

13. Lahiri A., Kobayashi S.-I. Electroless deposition of gold on silicon and its potential applications: review // Surf. Eng. 2016. - Vol.32. - P.321-337.

14. Composite porous silicon-silver nanoparticles as theranostic antibacterial agents / Kim T., Braun G.B., She Z.-G., Hussain S., Ruoslahti E., Sailor M.J. // ACS Appl. Mater. Interfaces. - 2016. - Vol.8. - P.30449-30457.

15. Preparation, characterization and antibiotic properties of silver-silicon nanocomposites / Chang H., Gao W., Sun X., Tan H., Sun S. // New J. Chem. - 2017. - Vol.41. - P.13131320.

16. Ordered arrays of vertically aligned [110] silicon nanowires by suppressing the crystallographically preferred $\langle 100\rangle$ etching directions / Huang Z., Shimizu T., Senz S., Zhang Z., Zhang X., Lee W., Geyer N., Gosele U. // Nano Lett. - 2009. - Vol.9. - P.2519-2525.

17. Extended arrays of vertically aligned sub-10 $\mathrm{nm}$ diameter [100] Si nanowires by metal-assisted chemical etching / Huang Z., Zhang X., Reiche M., Liu L., Lee W., Shimizu T., Senz S., Gosele U. // Nano Lett. - 2008. - Vol.8. - P.3046-3051.

18. Graphene- $A g$ hybrids on laser-textured $\mathrm{Si}$ surface for SERS Detection / Zhang C., Lin K., Huang Y., Zhang J. // Sens. (Basel). - 2017. - Vol.17. - Article No. 1462.

19. Grean T.A. Gold electrodeposition for microelectronic, optoelectronic and microsystem applications // Gold Bull. - 2007. - Vol.40. - P.105-114.

20. Philipsen H., Monnens $W$. Immersion and electrochemical deposition of $\mathrm{Ru}$ on $\mathrm{Si} / /$ Electrochim. Acta. 2018. - Vol.274. - P.306-315.

21. Nativ-Roth E., Rechav K., Porat Z. Deposition of gold and silver on porous silicon and inside the pores // Thin Solid 
Films. - 2016. - Vol.603. - P.88-96.

22. Selective palladium electrochemical deposition onto AFM-scratched silicon surfaces / Santinacci L., Djenizian T., Hildebrand H., Ecoffey S., Mokdad H., Campanella T., Schmuki P. // Electrochim. Acta. - 2003. - Vol.48. - P.3123-3130.

23. In situ FTIR monitoring of Ag and Au electrodeposition on glassy carbon and silicon / Marquez K., Ortiz R., Schultze J.W., Marquez O.P., Marquez J., Staikov G. // Electrochim. Acta. 2003. - Vol.48. - P.711-720.

24. AFM analysis for initial stage of electroless displacement deposition of silver on silicon surface / Ego T., Hagihara T., Morii Y., Fukumuro N., Yae S., Matsuda H. // ECS Trans. 2013. - Vol.50. - P.143-153.

25. DaRosa C.P., Iglesia E., Maboudian R. Dynamics of copper deposition onto silicon by galvanic displacement // J. Electrochem. Soc. - 2008. - Vol.155. - P.D244-D250.

26. Polavarapu L., Liz-Marzan L.M. Growth and galvanic replacement of silver nanocubes in organic media // Nanoscale. - 2013. - Vol.5. - P.4355-4361.

27. Silver nanostructures on silicon based on galvanic displacement process / Gutes A., Laboriante I., Carraro C., Maboudian R. // J. Phys. Chem. C. - 2009. - Vol.113. - P.1693916944.

28. Carraro C., Maboudian R., Magagnin L. Metallization and nanostructuring of semiconductor surfaces by galvanic displacement processes // Surf. Sci. Rep. - 2007. - Vol.62. P.499-525.

29. Effects of HF solution in the electroless deposition process on silicon surfaces / Nagahara L.A., Ohmori T., Hashimoto K., Fujishima A. // J. Vac. Sci. Technol. A. - 1993. - Vol.11. - P.763-767.

30. Electroless metallization of silicon using metal nanoparticles as catalysts and binding-points / Yae S., Enomoto M., Atsushiba H., Hasegawa A., Okayama C., Fukumuro N., Sakamoto S., Matsuda H. // ECS Trans. - 2013. - Vol.53. P.99-103.

31. Djokic S.S., Cadien K. Galvanic deposition of silver on silicon surfaces from fluoride free aqueous solutions // ECS Trans. - 2015. - Vol.4. - P.D11-D13.

32. Silver nanocrystals of various morphologies deposited on silicon wafer and their applications in ultrasensitive surfaceenhanced Raman scattering / Chen L., Jing Q., Chen J., Wang B., Huang J., Liu Y. // Mater. Charact. - 2013. - Vol.85. - P.48-56.

33. Galvanic deposition of gold on silicon from $\mathrm{Au}(\mathrm{I})$ alkaline fluoride-free solutions / Djokic S.S., Antic Z., Djokic N.S., Thundat T. // J. Electrochem. Soc. - 2016. - Vol.163. - P.D818D820.

34. Brahiti N., Bouanik S.-A., Hadjersi T. Metal-assisted electroless etching of silicon in aqueous $\mathrm{NH}_{4} \mathrm{HF}_{2}$ solution // Appl. Surf. Sci. - 2012. - Vol.258. - P.5628-5637.

35. Catalytic activity of noble metals for metal-assisted chemical etching of silicon / Yae S., Morii Y., Fukumuro N., Matsuda H. // Nanoscale Res. Lett. - 2012. - Vol.7. - Article No. 352.
36. Adhesion and interfacial structure of metal film electrolessly deposited on Si using Au nanoparticles as catalysts / Atsushiba H., Orita Y., Sakamoto S., Fukumuro N., Yae S. // ECS Trans. - 2014. - Vol.61. - P.9-13.

37. Nucleation behavior in electroless displacement deposition of metals on silicon from hydrofluoric acid solutions / Yae S., Nasu N., Matsumoto K., Hagihara T., Fukumuro N., Matsuda H. // Electrochim. Acta. - 2007. - Vol.53. - P.35-41.

38. Magagnin L., Maboudian R., Carraro C. Gold deposition by galvanic displacement on semiconductor surfaces: effect of substrate on adhesion // J. Phys. Chem. B. - 2002. - Vol.106. P.401-407.

39. Platinum monolayer electrocatalyst on gold nanostructures on silicon for photoelectrochemical hydrogen evolution / Kye J., Shin M., Lim B., Jang J.-W., Oh I., Hwang S. // ACS Nano. - 2013. - Vol.7. - P.6017-6023.

40. DaRosa C.P., Maboudian R., Iglesia E. Copper deposition onto silicon by galvanic displacement: effect of silicon dissolution rate // J. Electrochem. Soc. - 2008. - Vol.155. P.E70-E78.

41. Scudiero L., Fasasi A., Grifblths P.R. Characterization of a controlled electroless deposition of copper thin blm on germanium and silicon surfaces // Appl. Surf. Sci. - 2011. Vol.257. - P.4422-4427.

42. Magagnin L., Maboudian R., Carraro M. Selective deposition of thin copper films onto silicon with improved adhesion // Electrochem. Solid-State Lett. - 2001. - Vol.4. P.C5-C7.

43. Palladium nanostructures from galvanic displacement as hydrogen peroxide sensor / Gutes A., Laboriante I., Carraro C., Maboudian R. // Sens. Actuators B. - 2010. - Vol.147. - P.681686.

44. Niwa D., Homma T., Osaka T. Deposition behavior of $\mathrm{Ni}$ on $\mathrm{Si}(100)$ surfaces in an aqueous alkaline solution // J. Electrochem. Soc. - 2005. - Vol.152. - P.C54-C59.

45. Kuntyi O.I. Electrochemistry and morphology of disperse metals. - Lviv: Lviv Polytechnic National University. 2008. $-208 \mathrm{p}$.

46. Growth of nanogold at interfaces between locally induced naked silicon surfaces and pure $\mathrm{HAuCl}_{4}$ solutions / Itasaka $\mathrm{H}$., Nishi M., Shimizu M., Hirao K. // J. Electrochem. Soc. - 2016. - Vol.163. - P.D743-D746.

47. Modification of silicon surface with silver, gold and palladium nanostructures via galvanic substitution in DMSO and DMF solutions / Kuntyi O., Shepida M., Sus L., Zozulya G., Korniy S. // Chem. Chem. Technol. - 2018. - Vol.12. - P.305309.

48. Tsujino K., Matsumura M. Morphology of nanoholes formed in silicon by wet etching in solutions containing HF and $\mathrm{H}_{2} \mathrm{O}_{2}$ at different concentrations using silver nanoparticles as catalysts // Electrochim. Acta. - 2007. - Vol.53. - P.28-34.

49. Pore formation in silicon by wet etching using micrometre-sized metal particles as catalysts / Lee C.-L., Tsujino K., Kanda Y., Ikeda S., Matsumura M. // J. Mater. Chem. - 2008. 
- Vol.18. - P.1015-1020.

50. Motility of metal nanoparticles in silicon and induced anisotropic silicon etching / Peng K., Lu A., Zhang R., Lee S.-T. // Adv. Funct. Mater. - 2008. - Vol.18. - P.3026-3035.

51. Fabrication and characterization of high-performance anti-reflecting nanotextured Si surfaces for solar cells / Nichkalo S., Druzhinin A., Yerokhov V., Ostapiv O. // Springer Proceed. Phys. - 2018. - Vol.210. - P.275-283.

52. Densely packed arrays of ultra-high-aspect-ratio silicon nanowires fabricated using block-copolymer lithography and metal-assisted etching / Chang S.-W., Chuang V.P., Boles S.T., Ross C.A., Thompson C.V. // Adv. Funct. Mater. - 2009. Vol.19. - P.2495-2500.

53. Electroless patterned assembly of metal nanoparticles on hydrogen-terminated silicon surfaces for applications in photoelectrocatalysis / Fabre B., Hennous L., Ababou-Girard S., Meriadec C. // ACS Appl. Mater. Interfaces. - 2013. - Vol.5. - P.338-343.

Received 24.09.2018

\section{ОСАДЖЕННЯ НАНОСТРУКТУРОВАНИХ МЕТАЛІВ НА ПОВЕРХНЮ КРЕМНІЮ ГАЛЬВАНІЧНИМ ЗАМІЩЕННЯМ: МІНІ-ОГЛЯД}

\section{О.I. Кунтий, Г.I. Зозуля, М.В. Шепіда, С.І. Нічкало}

У міні-огляді проаналізовано публікації останнього десятиліття, присвячені вивченню процеса формування металевих наноструктур на поверхні кремнієвої підкладки методом гальванічного заміщення. Показано, що серед сучасних методів модифікації поверхні наноструктурами гальванічне заміщення розглядають як один з ефективних в аспекті одержання нових матеріалів $i$ нанесення металевих плівок. Найбільш вивчено осадження на поверхню кремнію наноструктурованих осадів срібла, золота, платинових металів та міді. Розглянуто особливості електродних реакцій за участю напівпровідника та компонентів розчину. Вказано на найбільш уживані методики нанесення металевих наночастинок і наноплівок на кремнієву поверхню. Наведено дані про вплив головних параметрів проце су гальванічного заміщення (склад розчину, тривалість осадження, температура) на морфологію осаду та геометрію осаджених частинок. Описано головні напрями застосування метал-кремнієвих гібридних структур одержаних гальванічним замішенням, а саме: метал-каталітичне хімічне травлення, створення електричних контактів на поверхні кремнію та високоефективних каталізаторів і сенсорів. Показано, що метод гальванічного заміщення забезпечує контрольований синтез наночастинок металів визначеної морфології, форми, розміру та розподілу на поверхні підкладки кремнію та ї̈ особливі функціональні властивості.

Ключові слова: гальванічне заміщення; кремній; наночастинки; срібло; золото; платина; паладій; мідь.

\section{DEPOSITION OF NANOSTRUCTURED METALS ON THE SURFACE OF SILICON BY GALVANIC REPLACEMENT: A MINI-REVIEW}

O.I. Kuntyi *, G.I. Zozulya, M.V. Shepida, S.I. Nichkalo

Lviv Polytechnic National University, Lviv, Ukraine

*e-mail: kunty@ukr.net

The paper overviews the publications of the last decade devoted to the formation of metallic nanostructures on the surface of the silicon substrate by the galvanic replacement method. Among modern methods of surface modification by nanostructures, galvanic replacement can be considered as one of the most effective in the aspect of obtaining new materials and applying metal films. The deposits of silicon nanostructures of silver, gold, platinum metals and copper are the most studied. The features of microelectrode reactions with the participation of the semiconductor and the components of the solution are discussed. The methods of metal nanoparticles and nanofilms deposition on the silicon wafer surface are reviewed. The data on the influence of the main parameters of the galvanic replacement process (composition of the solution, duration of precipitation and temperature) on the deposits' morphology and the geometry of the deposited particles are presented. The main directions in the application of metal-silicon hybrid structures obtained by galvanic replacement, namely metal-catalytic chemical etching, creation of electrical contacts on the surface of silicon and highperformance catalysts and sensors, are described. It has been shown that the galvanic replacement method provides controlled synthesis of metal nanoparticles of defined morphology, shape, size and distribution on the surface of silicon substrate and their special functional properties.

Keywords: galvanic replacement; silicon; nanoparticles; silver; gold; platinum; palladium; copper.

\section{REFERENCES}

1. Peng K.-Q., Lee S.-T. Silicon nanowires for photovoltaic solar energy conversion. Advanced Materials, 2011, vol. 23, pp. 198-215.

2. Nichkalo S., Druzhinin A., Evtukh A., Bratus' O., Steblova O. Silicon nanostructures produced by modified MacEtch method for antireflective Si surface. Nanoscale Research Letters, 2017, vol. 12, article no. 106.

3. Peng K., Jie J., Zhang W., Lee S.-T. Silicon nanowires for rechargeable lithium-ion battery anodes. Applied Physics Letters, 2008, vol. 93, article no. 033105 .

4. Zhang B., Wang H., Lu L., Ai K., Zhang G., Cheng X. Large-area silver-coated silicon nanowire arrays for molecular sensing using surface-enhanced Raman spectroscopy. Advanced Functional Materials, 2008, vol. 18, pp. 2348-2355.

5. Zhang M.-L., Yi C.-Q., Fan X., Peng K.-Q., Wong N.-B., Yang M.-S., Zhang R.-Q., Lee S.-T. A surface-enhanced Raman spectroscopy substrate for highly sensitive label-free immunoassay. Applied Physics Letters, 2008, vol. 92, article no. 043116.

6. Xiu Y., Zhu L., Hess D.W., Wong C.P. Hierarchical silicon etched structures for controlled hydrophobicity/ superhydrophobicity. Nano Letters, 2007, vol. 7, pp. 3388-3393.

7. Sayed S.Y., Wang F., Malac M., Meldrum A., Egerton R.F., Buriak J.M. Heteroepitaxial growth of gold nanostructures on silicon by galvanic displacement. ACS Nano, 2009, vol. 3, pp. 2809-2817. 
8. Yamada N., Atsushiba H., Sakamoto S., Fukumuro N., Yae S. Effect of epitaxial growth of gold nanoparticles on $\mathrm{Si}$ substrates on adhesion of electrolessly deposited metal films. ECS Transactions, 2015, vol. 69, pp. 59-63.

9. Raygani A., Magagnin L. Gold metallization of silicon by galvanic displacement. ECS Transactions, 2012, vol. 41, pp. 3-8.

10. Gutes A., Carraro C., Maboudian R. Ultrasmooth gold thin films by self-limiting galvanic displacement on silicon. $A C S$ Applied Materials \& Interfaces, 2011, vol. 3, pp. 1581-1584.

11. Wei Q., Shi Y.-S., Sun K.-Q., Xu B.-Q. Pd-on-Si catalysts prepared via galvanic displacement for the selective hydrogenation of para-chloronitrobenzene. Chemical Communications, 2016, vol. 52, pp. 3026-3029.

12. Ensafi A.A., Rezaloo F., Rezaei B. Electrochemical sensor based on porous silicon/silver nanocomposite for the determination of hydrogen peroxide. Sensors and Actuators B: Chemical, 2016, vol. 231, pp. 239-244.

13. Lahiri A., Kobayashi S.-I. Electroless deposition of gold on silicon and its potential applications: review. Surface Engineering, 2016, vol. 32, pp. 321-337.

14. Kim T., Braun G.B., She Z.-G., Hussain S., Ruoslahti E., Sailor M.J. Composite porous silicon-silver nanoparticles as theranostic antibacterial agents. ACS Applied Materials \& Interfaces, 2016, vol. 8, pp. 30449-30457.

15. Chang H., Gao W., Sun X., Tan H., Sun S. Preparation, characterization and antibiotic properties of silver-silicon nanocomposites. New Journal of Chemistry, 2017, vol. 41, pp. 1313-1320.

16. Huang Z., Shimizu T., Senz S., Zhang Z., Zhang X., Lee W., Geyer N., Gosele U. Ordered arrays of vertically aligned [110] silicon nanowires by suppressing the crystallographically preferred $\langle 100\rangle$ etching directions. Nano Letters, 2009, vol. 9, pp. 2519-2525.

17. Huang Z., Zhang X., Reiche M., Liu L., Lee W., Shimizu T., Senz S., Gosele U. Extended arrays of vertically aligned sub-10 nm diameter [100] Si nanowires by metal-assisted chemical etching. Nano Letters, 2008, vol. 8, pp. 3046-3051.

18. Zhang C., Lin K., Huang Y., Zhang J. Graphene-Ag hybrids on laser-textured Si surface for SERS Detection. Sensors (Basel), 2017, vol. 17, article no. 1462.

19. Grean T.A. Gold electrodeposition for microelectronic, optoelectronic and microsystem applications. Gold Bulletin, 2007, vol. 40, pp. 105-114.

20. Philipsen H., Monnens W. Immersion and electrochemical deposition of Ru on Si. Electrochimica Acta, 2018, vol. 274, pp. 306-315.

21. Nativ-Roth E., Rechav K., Porat Z. Deposition of gold and silver on porous silicon and inside the pores. Thin Solid Films, 2016, vol. 603, pp. 88-96.

22. Santinacci L., Djenizian T., Hildebrand H., Ecoffey S., Mokdad H., Campanella T., Schmuki P. Selective palladium electrochemical deposition onto AFM-scratched silicon surfaces. Electrochimica Acta, 2003, vol. 48, pp. 3123-3130.
23. Marquez K., Ortiz R., Schultze J.W., Marquez O.P., Marquez J., Staikov G. In situ FTIR monitoring of Ag and Au electrodeposition on glassy carbon and silicon. Electrochimica Acta, 2003, vol. 48, pp. 711-720.

24. Ego T., Hagihara T., Morii Y., Fukumuro N., Yae S., Matsuda H. AFM analysis for initial stage of electroless displacement deposition of silver on silicon surface. ECS Transactions, 2013, vol. 50, pp. 143-153.

25. DaRosa C.P., Iglesia E., Maboudian R. Dynamics of copper deposition onto silicon by galvanic displacement. Journal of the Electrochemical Society, 2008, vol. 155, pp. D244-D250.

26. Polavarapu L., Liz-Marzan L.M. Growth and galvanic replacement of silver nanocubes in organic media. Nanoscale, 2013, vol. 5, pp. 4355-4361.

27. Gutes A., Laboriante I., Carraro C., Maboudian R. Silver nanostructures on silicon based on galvanic displacement process. The Journal of the Physical Chemistry C, 2009, vol. 113, pp. 16939-16944.

28. Carraro C., Maboudian R., Magagnin L. Metallization and nanostructuring of semiconductor surfaces by galvanic displacement processes. Surface Science Reports, 2007, vol. 62, pp. $499-525$.

29. Nagahara L.A., Ohmori T., Hashimoto K., Fujishima A. Effects of HF solution in the electroless deposition process on silicon surfaces. Journal of Vacuum Science \& Technology A, 1993, vol. 11, pp. 763-767.

30. Yae S., Enomoto M., Atsushiba H., Hasegawa A., Okayama C., Fukumuro N., Sakamoto S., Matsuda H. Electroless metallization of silicon using metal nanoparticles as catalysts and binding-points. ECS Transactions, 2013, vol. 53, pp. 99-103.

31. Djokic S.S., Cadien K. Galvanic deposition of silver on silicon surfaces from fluoride free aqueous solutions. ECS Transactions, 2015, vol. 4, pp. D11-D13.

32. Chen L., Jing Q., Chen J., Wang B., Huang J., Liu Y. Silver nanocrystals of various morphologies deposited on silicon wafer and their applications in ultrasensitive surface-enhanced Raman scattering. Materials Characterization, 2013, vol. 85, pp. $48-56$.

33. Djokic S.S., Antic Z., Djokic N.S., Thundat T. Galvanic deposition of gold on silicon from $\mathrm{Au}(\mathrm{I})$ alkaline fluoride-free solutions. Journal of the Electrochemical Society, 2016, vol. 163, pp. D818-D820.

34. Brahiti N., Bouanik S.-A., Hadjersi T. Metal-assisted electroless etching of silicon in aqueous $\mathrm{NH}_{4} \mathrm{HF}_{2}$ solution. Applied Surface Science, 2012, vol. 258, pp. 5628-5637.

35. Yae S., Morii Y., Fukumuro N., Matsuda H. Catalytic activity of noble metals for metal-assisted chemical etching of silicon. Nanoscale Research Letters, 2012, vol. 7, article no. 352.

36. Atsushiba H., Orita Y., Sakamoto S., Fukumuro N., Yae S. Adhesion and interfacial structure of metal film electrolessly deposited on $\mathrm{Si}$ using $\mathrm{Au}$ nanoparticles as catalysts. ECS Transactions, 2014, vol. 61, pp. 9-13.

37. Yae S., Nasu N., Matsumoto K., Hagihara T., Fukumuro N., Matsuda H. Nucleation behavior in electroless displacement deposition of metals on silicon from hydrofluoric 
acid solutions. Electrochimica Acta, 2007, vol. 53, pp. 35-41.

38. Magagnin L., Maboudian R., Carraro C. Gold deposition by galvanic displacement on semiconductor surfaces: effect of substrate on adhesion. The Journal of Physical Chemistry B, 2002, vol. 106, pp. 401-407.

39. Kye J., Shin M., Lim B., Jang J.-W., Oh I., Hwang S. Platinum monolayer electrocatalyst on gold nanostructures on silicon for photoelectrochemical hydrogen evolution. ACS Nano, 2013, vol. 7, pp. 6017-6023.

40. DaRosa C.P., Maboudian R., Iglesia E. Copper deposition onto silicon by galvanic displacement: effect of silicon dissolution rate. Journal of the Electrochemical Society, 2008 , vol. 155, pp. E70-E78.

41. Scudiero L., Fasasi A., Grifuths P.R. Characterization of a controlled electroless deposition of copper thin blm on germanium and silicon surfaces. Applied Surface Science, 2011, vol. 257 , pp. 4422-4427.

42. Magagnin L., Maboudian R., Carraro M. Selective deposition of thin copper films onto silicon with improved adhesion. Electrochemical and Solid-State Letters, 2001, vol. 4, pp. C5-C7.

43. Gutes A., Laboriante I., Carraro C., Maboudian R. Palladium nanostructures from galvanic displacement as hydrogen peroxide sensor. Sensors and Actuators B: Chemical, 2010, vol. 147, pp. 681-686.

44. Niwa D., Homma T., Osaka T. Deposition behavior of $\mathrm{Ni}$ on $\mathrm{Si}(100)$ surfaces in an aqueous alkaline solution. Journal of the Electrochemical Society, 2005, vol. 152, pp. C54-C59.

45. Kuntyi O.I., Electrochemistry and morphology of disperse metals. Lviv Polytechnic National University Publishers, Lviv, 2008. 208 p.

46. Itasaka H., Nishi M., Shimizu M., Hirao K. Growth of nanogold at interfaces between locally induced naked silicon surfaces and pure $\mathrm{HAuCl}_{4}$ solutions. Journal of the Electrochemical Society, 2016, vol. 163, pp. D743-D746.
47. Kuntyi O., Shepida M., Sus L., Zozulya G., Korniy S. Modification of silicon surface with silver, gold and palladium nanostructures via galvanic substitution in DMSO and DMF solutions. Chemistry \& Chemical Technology, 2018, vol. 12, pp. 305-309.

48. Tsujino K., Matsumura M. Morphology of nanoholes formed in silicon by wet etching in solutions containing $\mathrm{HF}$ and $\mathrm{H}_{2} \mathrm{O}_{2}$ at different concentrations using silver nanoparticles as catalysts. Electrochimica Acta, 2007, vol. 53, pp. 28-34.

49. Lee C.-L., Tsujino K., Kanda Y., Ikeda S., Matsumura M. Pore formation in silicon by wet etching using micrometresized metal particles as catalysts. Journal of Materials Chemistry, 2008, vol. 18, pp. 1015-1020.

50. Peng K., Lu A., Zhang R., Lee S.-T. Motility of metal nanoparticles in silicon and induced anisotropic silicon etching. Advanced Functional Materials, 2008, vol. 18, pp. 3026-3035.

51. Nichkalo S., Druzhinin A., Yerokhov V., Ostapiv O. Fabrication and characterization of high-performance antireflecting nanotextured Si surfaces for solar cells. In: Fesenko O., Yatsenko L. (eds.) Nanooptics, nanophotonics, nanostructures, and their applications. NANO 2017. Springer Proceedings in Physics, 2018, vol. 210, pp. 275-283.

52. Chang S.-W., Chuang V.P., Boles S.T., Ross C.A., Thompson C.V. Densely packed arrays of ultra-high-aspect-ratio silicon nanowires fabricated using block-copolymer lithography and metal-assisted etching. Advanced Functional Materials, 2009, vol. 19 , pp. $2495-2500$.

53. Fabre B., Hennous L., Ababou-Girard S., Meriadec C. Electroless patterned assembly of metal nanoparticles on hydrogen-terminated silicon surfaces for applications in photoelectrocatalysis. ACS Applied Materials \& Interfaces, 2013, vol. 5, pp. 338-343. 